\title{
Citizen-Centric Approach to E-government: Can It Help in Overcoming the Digitalization Financing Obstacle? The Case of Electricity Meter in Egypt
}

\author{
Ola Al Sayed \\ Associate Professor \\ Faculty of Economics and \\ Political Science \\ Cairo University \\ Shadwa Esmat \\ Assistant Professor \\ Faculty of Economics and \\ Political Science \\ Cairo University

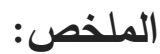 \\ تهدف الدراسة إلى تحديد العوامل المؤثرة على طلب المواطنين للخدمات الحكومية \\ الالكترونية وأثر ذلك على مصادر تمويل تلك الخدمات. كما تسعى الدراسة إلى تقديم \\ توصيات إلى صانع القرار الحكومي لدعم تصميم وتتفيذ أفضل للخدمات الحكومية \\ الالكترونية مبنى على احتياج وطلب المواطنين. وقد تم تصميم استبيان لدراسة طلب \\ المواطنين للخدمات الحكومية الالكترونية ممثلة في التقديم الإلكتروني على العداد

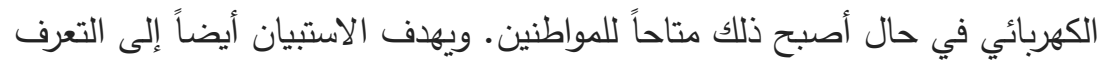 \\ على مدى رغبة وقبول المواطنين لدفع رسوم إضافية للحصول على الخدمة الالكترونية \\ في حال توفرها. تم جمع البيانات في الفترة من يوليو-أغسطس 2020 في القاهرة \\ الكبرى، وقد بلغ حجم العينة 400 مواطن. \\ توصلت الدراسة إلى أن الطلب على الخدمة الالكترونية محل الدراسة يتأثر ببعض مولن

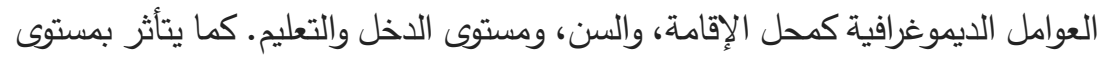


المعرفة لدى المواطنين عن الخدمات الحكومية الالكترونية المتاحة، ومدى توفر

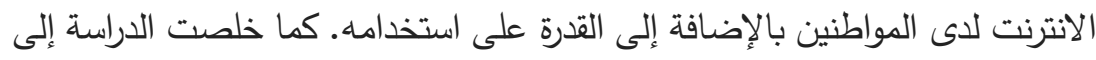

أن مدى الاستفادة المتوقعة أو الميزة النسبية للخدمات الالكترونية وسهولة استخدامها لأليا

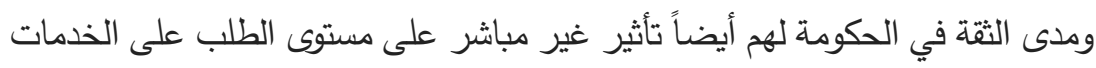

الحكومية الالكترونية. وقد طرحت الدراسة عدداً من التوصيات لصانع القرار لاختيار

وسيلة التمويل المناسبة للمشروعات الحكومية الالكترونية.

كلمات مفتاحية: الحكومة الاككترونية- الخدمات الالكترونية- الخدمات الحكومية

الالكترونية- تحديات الحكومة الالكترونية- الاستبيان - الرغبة في الدفع- التركيز

على المواطن - الثراكة بين القطاعين العام والخاص- الدول النامية- مصر - القاهرة

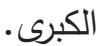

\section{Abstract}

The purpose of this study is to explore potential effects of households' demand for digital government services on the financing modes for these services. It aims as well at providing policy makers with recommendations that support a better design and implementation of digital government services based on citizens' demands. The researchers developed a survey to obtain citizens' demand for the online application for electricity meter, if available. The survey also seeks to discover if citizens have a willingness to pay (WTP) extra fees to get this new service. Data was collected in July-August 2020, from a sample of 400 respondents in Greater Cairo.

The research found that the demand for e-government service is affected by some demographic characteristics (area of residence, age, income, and education), level of knowledge about available online government services, internet use and accessibility or digital divide. In addition, relative advantage or perceived usefulness, ease of use and lack of trust showed indirect or implicit effect on the demand for e-government services that was revealed from citizens' answers to the survey. The study has implications regarding design, 
Citizen-centric Approach to e-government Ola AlSayed - Shadwa Esmat Accepted date 25/4/2021

implementation, and financing of e-government services. It provides insights to policymakers and governmental units to choose an appropriate financing mode for constructing and operating egovernment projects. In addition to determining the target groups of the e-government service in advance, to facilitate the transformation from traditional to digital service.

Keywords - E-government -E-service- Digital government service- E-government Challenges-Surveys - Willingness to pay (WTP)- Citizen centric approach - Public-private partnership Developing countries - Egypt - Greater Cairo.

\section{Introduction}

Governments around the world face lots of challenges when it comes to service delivery. That is why promoting government transformation using information technologies (digitalization) was seen as a step towards tackling some of these challenges. Digital government could be defined as the use of information and communication technologies (ICTs) to deliver government services more effectively and efficiently to citizens and businesses. Digitalized government services improve the internal workings of the public sector by reducing financial costs and transaction times and enable effective resource utilization across the various public sector agencies. Through digitalization, governments around the world can be more efficient, provide better services, respond to the demands of citizens for transparency and accountability, be more inclusive and thus restore the trust of citizens in their governments.

The adoption of information and communication technologies (ICT) in government services over the last decade has grown significantly across the globe, which has generated great opportunities and benefits for the governments, as well as, a 
number of challenges, such as insufficient human resources, technological infrastructure, lack of regulatory framework, diverse data formats, low digital literacy, lack of willingness to use new technologies, and large cost of constructing the required infrastructure for E-government services.

The current study explores the sources for financing government digital services, other than budgetary and borrowing channels, by revealing the preferences of users toward using these services and their willingness to pay extra user charge for benefit. These will create revenues that permit the private sector to share with government in providing these services. But these type of "publicprivate partnership" may end by failure with focus on "supply side" rather than "users demand", as non-use of these services or refusal of citizens to pay user charge will create what is called "latent demand" or demand without willingness to pay.

Dillard (1948), Kregel (1976) and Rogers (1989) explained the principle of effective demand as the key theoretical innovation of the General Theory ${ }^{1}$. It refers to the willingness and ability of consumers to buy goods and services at different prices, then it excludes "latent demand", where consumers do not have willingness to pay as a result of lack of knowledge or their low levels of incomes. Then, effective demand is the money actually spent by people on goods and services (Rogers, 2010).

Accordingly, the main goal of this paper is to analyze the extent to which citizens have demand for the online application for electricity meter in Egypt, if it becomes available. Then it will explore the most convenient source of financing for this service, by studying citizens' willingness to pay for the e-service. Accordingly, it can provide

${ }^{1}$ Keynes's principle of effective demand in chapter 3 of the General Theory. 

demand for the online service and how to overcome the financial challenge.

The introduction is followed by a review of the relevant literature in Section 2. Section 3 discusses the sources of financing digital services. The methodology, data and hypotheses development are provided in Section 4. Following this are the empirical results and discussion in Sections 5 and 6, respectively. Finally, section 7 concludes the paper along with some policy implications and suggestions for further research.

\section{Literature Review}

\section{2-1: Types of digitalization}

There are different types of e-government that is based on users' needs. (Alshehria and Drew, 2010 and Signore, Chesi and Pallotti, 2005) specified four types of e-government: the first -and the one applied in this study- is Government to citizens (G2C) where the majority of government services fall under. The main aim of this type is to serve and facilitate citizens' interaction with the government by making information available on the website besides having the ability to make certain transactions online. The second type is Government to Business (G2B) is mainly about the exchanged services between the government and business sector like for example obtaining permits, renewing licenses. The third type is Government to government $(\mathrm{G} 2 \mathrm{G})$ which is the online interaction between different government entities. It requires big government database. The fourth type is Government to employee $(\mathrm{G} 2 \mathrm{E})$ reflects the relationship between governments and its employees. The goal here is to offer online services for employees. (Hwang, et.al, 2004) added more types to egovernment like Citizen to citizen $(\mathrm{C} 2 \mathrm{C})$ and Business to business (B2B) e-government, where the government plays the role of mediator for the exchange of information in the two types.

$\underline{2-2: \text { Benefits of digitalization }}$ 
In today's globalized world, and with the continuous development of information technology worldwide, digitalization became a necessity and a target as well. Governments, both in developed and developing countries, cannot ignore that fact when looking for their own development and looking after the satisfaction of their citizens. Moreover, e-government services are not only about the use of technology or web-based internet applications to provide services, but more about citizens' empowerment and providing them with more opportunities to participate, increasing transparency, besides the initial goal which is improving government efficiency.

Digitalization of government services help governments increase efficiency, and reduce costs associated with the delivery of public services. It also helps governments in reaching new solutions and ideas that address complex challenges (Ojha and Pandey 2014). A recent example that directed more attention towards the importance of digitalization is corona virus pandemic (COVID 19) that started in late 2019 and continues in 2020 (till the time of writing this paper). During the complete or partial lock-down in the aftermath of the pandemic, the importance of digitalization of government services was felt by all citizens. Concepts like working from home, apply for/order the services online and have them delivered to your house, fill-in your tax-statements online, pay for your government services online...etc became the main theme for citizens' daily life. Governments with strong digital system were able to better serve the citizens (i.e., despite the pandemic, citizens can get the services through the online system) compared to others with no or weak digital government system. Consequently, more attention is directed towards how to invest more in government digitalization projects given the related challenges of adding additional burden on governments' budgets. (AlShehri and Drew, 2010) listed various benefits of adoption egovernment services, either for suppliers or users, such as: high quality of services delivery, low operating costs, improving transparency by reducing corruption, facilitating sharing 
information, building high trust with citizens and consolidating government services.

\section{2-3: Obstacles of digitalization}

Undoubtedly, the digitalization process of government services faces many challenges that the government has to go through and tries to overcome. Devaluing or misunderstanding of the challenges and risks associated with digitalization projects can lead to its failure. One of the first challenges to the digitalization process is technical issues (Signore, Chesi and Pallotti, 2005, Hwang et.al, 2004, Ojha and Pandey 2017). Since no one starts from scratch, thus having a solid IT infrastructure associated with the interoperability with existing platforms is an obvious obstacle. Also, technically handling and securing of citizens' privacy and transactions are a big challenge given that citizens' data has to be provided to get the digital services.

Additionally, there are social or cultural challenges associated with the usability of digital services since users are usually nonexperts and lack the cognition of using information services. Aside from the illiteracy rate that characterizes the Egyptian society. An equally important social challenge is the acceptance of both citizens and government employees to the digitalization process, with all required changes internally like problems of authority and responsibility, or externally like issues of trust and confidence on the new system (Hwang et.al, 2004, Signore, Chesi and Pallotti, 2005).

On the other hand, economic and financial challenges became notably on the top of the challenges of the digitalization process especially in developing countries. This is for the simple reason that the availability of finance is a key starting point required to initiate, operate and maintain the digitalization process. Though some authors didn't refer to economic challenges of digitalization process (Hwang et.al, 2004, Alshehri and Drew 2010). Others have stressed on it, like Alshehri and Drew who added the financial barrier (2011), Edmiston 2003) 
The literature differed in the classifications of obstacles that hinder the efficiency of e-government services, few studies have focused on funding issues. (Signore, Chesi and Pallotti, 2005) and (Layne and Lee, 2001) classified the obstacles based on the growth stage of the e-government. Technical, economical, and social issues are the main challenges. According to (Signore, Chesi and Pallotti, 2005), technical issues are related to IT infrastructure construction, security and privacy aspects, while economic challenges are based on cost/benefit analysis of the egovernment services. Besides social obstacles as a result of exclusion of some categories of people from using the egovernment services like illiterate and elderly people.

(Layne and Lee, 2001) added two challenges related to demand of e-government services, access to services, privacy and confidentiality, as services should be available to one hundred percent of citizens taking into consideration the privacy of their life and confidentiality of their personal data.

(Hwang, et.al, 2004) proposed different challenges to egovernment services, including technical, political, cultural, and legal aspects. Political resistance may hinder the standardization of e-services to protect the user's right. From cultural perspective, the human psychological factor brings a lot of difficulty in using e-government services especially in case of illiterate people. Furthermore, problems related to networking and security threats are the main issues as legal obstacles like hacker attacks and viruses.

(Nath and Kanjilal, 2014) agreed with previous studies on the political and technical challenges and added the bureaucracies in government organizations that hinder the effectiveness of egovernment services and reduce the benefits that the stakeholders receive. 
(Edmiston, 2003) studied these challenges in local governments and stated that obstacles related to the demand like marketing, privacy and equity are no less important than supply factors mainly financing obstacle. He argued that, on demand side, it is not enough to build the governmental websites but users should be educated and informed about the availability of these online services to achieve efficient marketing for these services. While equity stressed on the gap in delivering the services across different social categories. The financing obstacle in supply side arises from two complex problems; first, high cost of providing traditional and online services during transition to digital government. The second problem is large fixed costs and immediate expenditure for required investments in short run during construction the services, and savings in long run by gradual reduction in operating costs.

While few studies only analyzed the funding obstacle, (Chen and Thurmaier, 2008) referred that, the financing obstacle is the most important and complex barrier that hinder the development of egovernment services. This result is consistent with previous studies like (Holden, Norris and Fletcher, 2003), (Johnson, 2002) and (Noris and Moon, 2005).

In light with the countries' experiences with e-government obstacles, (Siddiqi, Btoush and Al-Adaieh, 2009), conducted a survey of 484 participants, each of them was given a questionnaire about the barriers of e-services development in Jordan. The respondents revealed that policy, economic, technical, skills and organizational factors are the main obstacles that hinder the provision of these services. While the study of (AlShboul et.al, 2014) added more challenges to Jordan case with adoption of e-government services. Most of them are related to demand side such as: lack of citizens' awareness and weak trust 
or believing in e-government services. Other obstacles are related to supply side such as: financial barriers and resistance of public employees. However, the study of (Rabaa, 2015) emphasized on the ease of use these services by citizens in Jordan by conducting a survey from 853 online users and ended that the difficult of using e-government is the most serious challenge to develop these services.

While the story was different for the Kingdom of Saudi Arabia, as many challenges and barriers faced e-government services such as cultural, technological, social, and organizational issues. (AlShehri and Drew, 2010) used an online survey to identify these barriers from the Saudi citizens' perspective to generate possible strategies for successful adoption of e-government services in Saudi Arabia. The survey ordered the obstacles according to its relative importance based on the respondents' point of view, starting with the IT infrastructure weakness, lack of knowledge about the e-government program, lack of security and privacy of information, and finally shortage of financial resources. From supply side, financial barrier is the most and serious to egovernment, including: limited financial spending and high cost of information technology, in addition to high price of providing these services. To overcome the financial barriers, Saudi Arabia government increases the budget assigned to support the spending on e-government services.

The study of (AlShehri, Drew and AlFarraj, 2012) conducted a survey of 460 Saudi citizens and IT department employees from different public sectors to determine the e-government obstacles. The shortage of financial resources of e-government sectors represented $50 \%$ of e-government services obstacles from Saudi citizen's perspective, while it represented 70\% from employee's perspective. While (Basamh, Qudaih and Suhaimi, 2014) stated 
different challenges for e-government implementation in Saudi Arabia. Accessibility, availability, and computer literacy are the most significant obstacles that prevent a large number of Saudis from using e-government services.

\section{Financing Government Digital Services}

Most of the previous studies endorsed using traditional budgetary sources to finance e-government services like; taxes, fees, and borrowing. But choosing the funding source for e-government services could depend on the stage of growth for these services, as during the "cataloguing" stage, the administrative websites could be initially financed using budgetary resources. While moving toward (G-to-C) or transaction stage, the traditional financing by budgetary resources mainly taxes become no longer sufficient to satisfy the provision of e-government services. Therefore, new financing sources should be adopted to avoid dependence on budgetary resources.

(Johnson, 2002) proposed multi-sourcing financing strategy for e-government services. Firstly, traditional financing by taxes. Secondly, issuing municipal bonds by local government, either general obligation bonds that use the local taxes revenues to repay the debts and its interest payments, or revenue bonds that depend on the user charges for e-government services to cover the debt and its interest payments. Thirdly, fully financed by private firm, if the discounted value of expected future net cash flows from service operations will be higher than the cost of investment. The revenues could be generated from user charge for using online services, this user charge is different from user fee that should be paid for traditional services. Lastly, the partnership with the private firm. (Chen and Thurmaier, 2008) suggested the same financing tool in construction and provision these services as a 
type of "public-private partnership model" (PPP), where the public investment and user charges are the main source of financing e-government services. (Ojha and Pandey, 2017) studied the PPP model in India in providing the e-government projects comparing with projects financed by traditional budgetary resources, and ended that projects financed by traditional sources experienced high level of risk, shortage in funding sources and technical problems.

The price of e-government services is called "a user charge". It is an additional charge, above user fees, for using online services. There are many benefits for user charge, mainly improving equity as it is voluntary paid only by online services users and that will enhance efficient resource allocation according to price signals. In addition to reduce congestion with charging high prices during peak times (Johnson, 2002).

The current study aims for helping governments in overcoming the financial challenges of merely depending on traditional financial methods of budgeting that create large fiscal burden and may lead to failure in maintaining and sustainability of digital services. But financing these services either by private sector or by public-private partnership requires affirming that consumers indeed have effective demand that generates a stream of revenues by paying the user charges.

However, determining the user charge is challenging as it requires bridging the gap between citizens and their government. Ultimately, citizens are the primary and most important stakeholder of digital services, then government need to assure self-interest of them in using these services and paying the user charge. On the other hand, it is imperative for citizens to understand the benefits they will have from using e-government services to create incentives for paying user charges. 
Despite the efforts exerted by many countries in digitalization, some of the digitalization projects ended by failure. Studies showed that one of the main reasons of failure was that many projects were driven by a focus on "technology supply" rather than "citizens' demands". Likewise, lack of users/stakeholders' involvement may create resistance or non-use of the e-services, and thus a failure of the project (Tassabehji, Hackney and Maruyama, 2019). Not to mention, if e-government services after being developed, are not used by citizens, it will be a big cost on the government's budget. It will even require more cost to amend it to fit to citizens' needs later. Therefore, it is vital for governments -especially in developing countries- to understand what citizens need from e-government services and then design digitalization projects based on their demands. Thus, it is important when studying e-government projects to keep an eye on citizens' needs and expectations from these projects.

Citizens adoption of e-government service is an important determinant for the success of e-government projects. These projects will fail If they are not used by the citizens. The literature in e-government adoption is divided mainly into two streams: the first focuses on the supply side (factors important to the supplier of e-service like infrastructures, skilled personnel, and financial resources). The second stream focuses on the demand side (citizens' perspectives and factors like usefulness, ease of use, quality and trust) (Al-hurjan et al., 2015, Ahmad, Markkula and Oivo, 2013)

When analyzing government efforts in the digitalization of public services, the focus should not only be on efficiency, but it should have a broader perspective on its impact on public value. Using the public value approach in analysis came as a further development in the literature of public administration after New Public Management (NPM). 
Public Administration in both theory and practice always tries to respond to new challenges and shortcomings of the running system. Accordingly, there has been a development from the Traditional Public Administration -where the main concern was efficiency- to New Public Management (NPM) -with concern for both efficiency and effectiveness- (Bryson, Crosby and Bloomberg, 2014), but with a private sector lens.

However, there were lots of challenges associated with NPM. For instance, given the private sector framework of NPM, government reforms based on NPM do not consider the social and political dimensions of public sector reform (Cordella and Bonina 2012). Consequently, many countries have moved away from the Traditional Public Administration-NPM debate to think about a Joined-Up Approach or Collaborative public Management (Cordella and Bonina, 2012).

Therefore, scholars started to draw attention to another foundation which is the emphasis on public values, citizenship, and collaborative governance (Bryson, Crosby, and Bloomberg, 2014). Citizens are seen not just as voters, clients, or customers, but as problem solver and co-creators who participate in producing what is valued by the public. Citizens give value for things that is far beyond the individual self-interest. In that sense, they do not behave as customers with economic objectives only for what they consume. They have visions, goals, and aspiration for the society. Thus, they value collective principles such as equality, justice, fairness, and trust (Cordella and Bonina 2012). Hence, the public value approach requires searching for solutions that ensure consistency between citizens' expectations and the actual delivered governmental goods or services. So, a government that is concerned about the creation of public value, shall not design the objectives based only on efficiency and effectiveness (NPM sprit) but also with the aims at creating values like fair and just society.

Accordingly, when studying public services digitalization projects, it should also be studied from the angle where it can help 
in the creation of public value besides its main role in delivering an efficient public service. Therefore, digitalization of government services can be used as a tool to build public trust, improve confidence, and stimulate a participatory relationship between citizens and the government. In other words, an efficient digitalized government project, can lead to an effective program which in turn can increase public trust, and vice-versa. (Cordella and Bonina 2012).

So, the paper aims at revealing the extent to which citizens have demand for the digitalization of electricity meter's application process. The researchers will consider the public value approach; where citizens are looking for both an efficient and effective eservice, and the associated public values. The paper will also seek to expose how much citizens are willing to pay -if any- to get that e-service. By knowing whether citizens will be willing to pay extra fees or not to get the e-service, this shall give guidance to the government whether or not to finance these services from other sources than the budget, like the private sector or through a partnership with the private sector.

4) Methodology, Sample, and Hypotheses development

\section{4-1 Methodology:}

To obtain citizens' demand for the online application for electricity meter, if available. as well as to discover if they are willing to pay extra fees for this new service, the researchers developed a survey.

The researcher-completed survey method was employed. This approach means that the researcher read the questions to the respondents and record their response. This method was used to maximize the response rate compared to self-administered survey (Carter and Weerakkody, 2008). Also, to consider the level of illiteracy in Egypt.

The survey is divided into three sections. the first one shows the demographic and social characteristics of the sample. It is important to understand to what extent the demographic 
characteristics have an impact on the demand of the respondents. In this section, some questions were asked to reveal the extent to which the respondent is an internet user, has debit/credit card, and if he previously used online payment.

The second section of the survey includes questions that aims at disclosing the factors affecting the respondents' attitude towards online service. So, respondents were asked about their knowledge of the existence of online government services, if they ever used them, their evaluation for such experience, and also their experience with the traditional application method for electricity meter and their evaluation for that experience.

In the third section of the survey, the respondent is asked whether he will choose to use the new online service if it becomes available or not. This shall help measure the level of demand for the new online service. If the respondent answered no to this question, then he is asked about reasons of refusal. If the respondent answered yes, he/she is then asked if they are willing to pay to get this new online service, and the maximum amount they are willing to pay. The researchers will depend on the direct open-ended question to reveal willing to pay $\left(\mathrm{WTP}^{2}\right)$ where respondents are asked directly about the maximum amount, they are willing to pay to for the service if it became available online. Even though this format has some problems since open-ended questions can lead to high non-response rates, zero answers, or outliers. On the other hand, the open-ended format does not provide respondents with any clues about the value. Thus, it is an informative method since the maximum WTP can be identified for each respondent and requires relatively straightforward statistical techniques (OECD,2018). It also helps overcoming the starting point bias.

${ }^{2}$ That format is expected to provide the range of WTP values that will be used in another paper by the researchers. The paper will depend on the doublebounded dichotomous choice format for the elicitation question to determine the factors that affects respondents' WTP for the service. 


\section{4-2: The Sample:}

\section{4-2-1: Sample Size:}

The sample size -assuming infinite population- is determined according to the following formula (Keller.G, Warrack.B, 1999). $n_{0}=\frac{z_{\alpha}^{2} * p *(1-p)}{e^{2}}$.

Where $Z_{\alpha}$ is the critical value of the Normal distribution at $\alpha$ (e.g. for a confidence level of $95 \%, \alpha$ is 0.05 and the critical value is 1.96 ), and $\mathrm{p}$ is the percentage of specific phenomena and set to be 0.5 as it gives the highest value for sample size, e is the margin error and set to be 0.05 Then the sample size is at least 384 persons.

The questionnaire will be implemented on Greater Cairo that includes: Cario, Giza and Qalyobia. According to the last census in 2017, the percentage of population in Cairo with respect to Great Cairo is 38\%, and in Giza also is 38\%, while in Qalyobia is $24 \%$. These percentages were considered in the distribution of the questionnaire.

\section{4-2-2: Sample Profile/ Socio-demographic characterises of the respondents:}

With the help of 6 field researchers, a total of 400 questionnaires were completed in a face-to-face interview during July-August $2020^{3}$. It was a preferable collection method to ensure response and to consider the illiteracy rate in some areas. Each questionnaire took around 10-15 minutes to complete. Table (1) shows the socio-demographic characteristics of the sample.

\footnotetext{
${ }^{3}$ COVID19 represented a challenge in the collection of the questionnaire especially that it was collected face-to-face. Thus, the researchers considered all the requirements and safety precautions needed, and the questionnaire was collected in 2 months instead on one as planned.
} 
Table (1): Socio-demographic profile of the sample:

\begin{tabular}{|l|l|l|}
\hline Characteristics & Frequency & $\%$ of $(\mathrm{n}=400)$ \\
\hline Governorate: & & \\
\hline Cairo & 156 & 39.0 \\
\hline Giza & 138 & 34.5 \\
\hline Qalyobia & 106 & 26.5 \\
\hline Gender: & & \\
\hline Male & 208 & 52.0 \\
\hline Female & 192 & 48.0 \\
\hline Age: & & \\
\hline Less than 40 & 209 & 52.3 \\
\hline More than 40 & 191 & 47.8 \\
\hline Social Status: & & \\
\hline Single/engaged & 79 & 19.8 \\
\hline Married & 289 & 72.3 \\
\hline Divorced/widowed & 32 & 8.0 \\
\hline Averaged Monthly Salary & & \\
\hline Less than 1000 & 6 & 1.5 \\
\hline 1000-3000 & 233 & 58.3 \\
\hline 3000-5000 & 151 & 37.8 \\
\hline More than 5000 & 10 & 2.5 \\
\hline Educational Status & 13 & 22.0 \\
\hline Illiterate & 88 & 1.8 \\
\hline Less than intermediate & 175 & \\
\hline Intermediate & 7 & \\
\hline University level & & \\
\hline Postgraduate & & \\
\hline Source: constructed & \\
\hline
\end{tabular}

\section{Source: constructed by the researchers}

\section{4-3: The correlation measures}

Measuring the correlation between factors tested by the study and demand for online application for electricity meter, if available is based on the following correlation measures (Keller.G and Warrack.B, 1999, Black, K., 1994, Agresti, A., 2007): 
Odds ratio: ratio between the probability of success and the probability of failure. It uses when we have two variable each have two categories. The odds can range from 0 to infinity with odds larger than 1 indicating that a success is more likely than a failure. When odds equal to 1 and when the confidence interval contain 1 then the two variables are independent.

Chi-square test: test if there is a sig relationship between two variables at least one of them have more than two categories. Its null hypothesis is the two variables are independent, the alternative hypothesis is the two variables are dependent.

Gamma: ordinal measure of association, use when we have two ordinal variable one of them have more than two categories. It can range from -1 to 1 , when gamma equal to 0 then the two variables are independent.

T-test: test if there is a significant difference between the means of two groups, which may be related in certain features.

4-4: Hypotheses: Based on the literature and the description of factors, we can formulate in table (2) the study's hypotheses. 
Citizen-centric Approach to e-government Ola AISayed - Shadwa Esmat Accepted date 25/4/2021

Table (2): Research Hypotheses:

\begin{tabular}{|c|c|c|}
\hline $\begin{array}{c}\text { The independent } \\
\text { variables }\end{array}$ & & Hypothesis \\
\hline Residence & H1 & $\begin{array}{l}\text { The area of residence (governorate) has NO effect on demand } \\
\text { for online application for electricity meter, if available. }\end{array}$ \\
\hline Gender & $\mathrm{H} 2$ & $\begin{array}{c}\text { The gender has NO effect on demand for online application for } \\
\text { electricity meter, if available. }\end{array}$ \\
\hline Age & $\mathrm{H} 3$ & $\begin{array}{c}\text { The age has a negative effect on demand for online application } \\
\text { for electricity meter, if available. }\end{array}$ \\
\hline Social status & $\mathrm{H} 4$ & $\begin{array}{c}\text { Social status has NO effect on demand for online application for } \\
\text { electricity meter, if available. }\end{array}$ \\
\hline $\begin{array}{l}\text { Average monthly } \\
\text { salary }\end{array}$ & H5 & $\begin{array}{l}\text { There is a positive relationship between average monthly salary } \\
\text { and demand for online application for electricity meter, if } \\
\text { available. } \\
\text { H5-1: low-income respondents (with income less than } 3000 \text { ) have } \\
\text { LOW demand } \\
\text { H5-2: high income respondents (with income } 3000 \text { and more) have } \\
\text { HIGH demand }\end{array}$ \\
\hline Educational level & H6 & $\begin{array}{l}\text { There is positive relationship between the educational level and } \\
\text { demand for online application for electricity meter, if available. } \\
\text { H6-1: illiterate and less than intermediate respondents do not have } \\
\text { demand. } \\
\text { H6-2: respondents with intermediate educational level have LOW } \\
\text { demand. } \\
\text { H6-3: respondents with university level and above have HIGH } \\
\text { demand. }\end{array}$ \\
\hline $\begin{array}{l}\text { Knowledge about } \\
\text { existing online } \\
\text { government services }\end{array}$ & $\mathrm{H} 7$ & $\begin{array}{l}\text { Knowledge about existing online government services has } \\
\text { positive effect on demand for online application for electricity } \\
\text { meter, if available. }\end{array}$ \\
\hline $\begin{array}{l}\text { Internet accessibility } \\
\text { and usage }\end{array}$ & $\mathrm{H} 8$ & $\begin{array}{l}\text { Internet accessibility and usage has positive effect on the } \\
\text { demand for online application for electricity meter, if available. }\end{array}$ \\
\hline $\begin{array}{l}\text { respondents' } \\
\text { experience with } \\
\text { government services }\end{array}$ & H9 & $\begin{array}{l}\text { H9-1: Traditional applying with more obstacles, less quality and } \\
\text { high cost have positive effect on demand for online application for } \\
\text { electricity meter, if available. } \\
\text { H9-2: the experience of respondents with using the online } \\
\text { government services, either in terms of usage or evaluation has } \\
\text { positive effect on demand for online application for electricity } \\
\text { meter, if available. }\end{array}$ \\
\hline
\end{tabular}

Source: constructed by the researchers 


\section{5) Empirical Results:}

The results of the survey showed the impact of the four main categories of factors on the demand for applying electricity meter, if available online. The factors include: (1) demographic variables, (2) knowledge about existing online government services, (3) internet accessibility and usage and (4) respondents' experience with government services either traditional or digital. The respondents' demand was inferred through their response to a Yes/No question that asked them if applying for the electricity meter became available online, would you like to use this service. In addition to the impact of these variables, another important result is derived from the survey was the maximum amount respondents were willing to pay for getting the online service if become available for electricity meter. These results are illustrated below.

\section{5-1: Demographic variables:}

Table (3) shows the distribution of respondents' answers to "yes" and "no" for the following question "if applying for an electricity meter became available online, would you like to use this service?", to elicit their demand for this service. The question did not refer to any price or user charge to benefit from it. The respondents' answers to "yes" or "no" are classified in the table according to their socio-economic characteristics to reveal how their demand could be affected by these characteristics.

Regarding the correlation between socio-economic characteristics of respondents and their demand for online applying for electricity meter, if available, the socio-economic factors do not have the same effect on respondents' demand as they include positive, negative and no effect.

There is a weak relationship between residence and demand, while gender and social status have no effect on demand. 
Nevertheless, both average monthly salary and educational status have positive effect on demand, as the odds of using service for those whose averaged monthly salary is less than 3000 is less than the odds of using service for those whose averaged Monthly salary is more than 3000 by $54 \%$. Similarly, respondents with high salary have great demand for using this service if available. On contrary, the odds of using service for who is less than 40 years old is 2.32 times the odds of using the service if it became online service for who is more than 40 years old, then there is negative effect of age on the demand for digital government services, as the demand falls for elder respondents.

Table (3): Distribution of answers to positive answers (Yes) and negative answers (No) by socio-economic characteristics and their correlation with accepting to use the service if applying for an electricity meter became available online.

\begin{tabular}{|c|c|c|c|c|}
\hline \multicolumn{5}{|c|}{$\begin{array}{l}\text { The question that respondents had been asked to elicit their demand } \\
\text { for the online service: } \\
\text { If applying for an electricity meter became available online, would } \\
\text { you like to use this service? }\end{array}$} \\
\hline $\begin{array}{l}\text { Socio- } \\
\text { economic } \\
\text { characteristics }\end{array}$ & $\begin{array}{l}\text { Classifications of } \\
\text { respondents }\end{array}$ & Yes & No & $\begin{array}{l}\text { Correlation } \\
\text { Coefficients }\end{array}$ \\
\hline \multirow[t]{3}{*}{ Residence } & $34.5 \%$ from Giza & $84.1 \%$ & $15.9 \%$ & \multirow{3}{*}{$\begin{array}{l}\text { Chi-square } \\
\text { value }=11.299 \\
\text { Chi-square } \\
\text { Sig. }=0.023<5 \% \\
\text { Contingency } \\
\text { coefficient = } \\
(0.166)\end{array}$} \\
\hline & $39 \%$ from Cairo & $92.9 \%$ & $7.1 \%$ & \\
\hline & $\begin{array}{l}26.5 \text { from } \\
\text { Qalyobia }\end{array}$ & $80.2 \%$ & $19.8 \%$ & \\
\hline \multirow[t]{2}{*}{ Gender } & $52 \%$ males & $89.4 \%$ & $10.6 \%$ & \multirow{2}{*}{$\begin{array}{l}\text { Chi-square } \\
(0.983-3.132) \\
\text { Odds ratio }= \\
1.755\end{array}$} \\
\hline & $48 \%$ females & $82.8 \%$ & $17.2 \%$ & \\
\hline Age & $52.2 \%$ less than 40 & $90.9 \%$ & $9.1 \%$ & $\begin{array}{l}\text { Chi-square } \\
(1.281-4.210)\end{array}$ \\
\hline
\end{tabular}


Citizen-centric Approach to e-government Ola AlSayed - Shadwa Esmat Accepted date 25/4/2021

\begin{tabular}{|c|c|c|c|c|}
\hline & $\begin{array}{l}47.8 \% \text { more than } \\
40\end{array}$ & $81.2 \%$ & $18.8 \%$ & $\begin{array}{l}\text { Odds ratio }= \\
2.323\end{array}$ \\
\hline \multirow{2}{*}{ Social status } & $723 \%$ married & $875 \%$ & $125 \%$ & \multirow{2}{*}{$\begin{array}{l}\text { Chi-square } \\
(0.793-2.657) \\
\text { Odds ratio = } \\
1.451\end{array}$} \\
\hline & $27.7 \%$ others & $82.9 \%$ & $17.1 \%$ & \\
\hline & & & & \\
\hline \multirow[t]{2}{*}{$\begin{array}{l}\text { Average } \\
\text { monthly salary }\end{array}$} & $\begin{array}{l}60 \% \text { less than } \\
3000 \mathrm{LE} / \text { month }\end{array}$ & $82.8 \%$ & $17.2 \%$ & \multirow{2}{*}{$\begin{array}{l}\text { Chi-square } \\
(0.242-0.875) \\
\text { Odds ratio }= \\
0.460\end{array}$} \\
\hline & $\begin{array}{l}40 \% \text { more than } \\
3000 \mathrm{LE} / \text { month }\end{array}$ & $91.3 \%$ & $8.7 \%$ & \\
\hline \multirow[t]{3}{*}{$\begin{array}{l}\text { Educational } \\
\text { level }\end{array}$} & $\begin{array}{l}25.2 \% \text { Illiterate } \\
\text { and less than } \\
\text { intermediate }\end{array}$ & $67 \%$ & $33 \%$ & \\
\hline & $\begin{array}{l}43.8 \% \\
\text { intermediate }\end{array}$ & $90 \%$ & $10 \%$ & \multirow{2}{*}{$\begin{array}{l}\text { Chi-square } \\
\text { value }=42.774 \\
\text { Chi-square } \\
\text { Sig. }=0.000<5 \% \\
\text { Gamma = }(- \\
0.66)\end{array}$} \\
\hline & $\begin{array}{l}31 \% \text { university } \\
\text { level and post } \\
\text { graduate }\end{array}$ & $96 \%$ & $4 \%$ & \\
\hline
\end{tabular}

Source: constructed by the researchers

\section{5-2: Knowledge about existing online government service:}

Table (4) shows the effect of knowledge about existing online government services on demand for online applying for electricity meter, if available. The results reveal that there is positive effect of knowledge on the demand for this service, as the odds of using service for those whose do not have knowledge is less than the odds of using service for those whose have knowledge by $46 \%$. 
Table (4): Distribution of answers to positive answers (Yes) and negative answers (No) according to the respondents' knowledge about existing online government services and its correlation with accepting to use the service if applying for an electricity meter became available online

\begin{tabular}{|c|c|c|c|c|}
\hline \multicolumn{5}{|c|}{$\begin{array}{l}\text { The question that respondents had been asked to elicit their demand } \\
\text { for the online service: } \\
\text { If applying for an electricity meter became available online, would } \\
\text { you like to use this service? }\end{array}$} \\
\hline & $\begin{array}{l}\text { Classifications of } \\
\text { respondents }\end{array}$ & Yes & No & $\begin{array}{l}\text { Correlation } \\
\text { Coefficients }\end{array}$ \\
\hline \multirow[t]{2}{*}{$\begin{array}{l}\text { Knowledge } \\
\text { about } \\
\text { existing } \\
\text { online } \\
\text { government } \\
\text { services }\end{array}$} & $\begin{array}{l}34 \% \text { of respondents do } \\
\text { not have information } \\
\text { about the availability } \\
\text { of online government } \\
\text { services }\end{array}$ & $67.9 \%$ & $31.4 \%$ & \multirow[t]{2}{*}{$\begin{array}{l}\text { Chi-square } \\
(0.312-0.906) \\
\text { Odds ratio }= \\
0.54\end{array}$} \\
\hline & $\begin{array}{l}66 \% \text { of respondents } \\
\text { have information about } \\
\text { the availability of } \\
\text { online government } \\
\text { services }\end{array}$ & $95.8 \%$ & $4.2 \%$ & \\
\hline
\end{tabular}

\section{Source: constructed by the researchers}

\section{5-3: Internet accessibility and usage:}

The findings in table (5) show the effect of internet accessibility and usage of respondents on the demand. Concerning the accessibility to internet, $80 \%$ of respondents have access to internet. The study expressed the factor usage of internet by respondents in terms of several sub-factors including, having smart phones, computers, or tablets, having credit or debit card, using online payments before and using online banking services before. The hypothesis (H8) assumed positive effect of internet usage on demand.

The results in table (5) confirmed our expectations as reflected in (H8), as all sub-factors have positive effect on demand. In respect 
to internet accessibility, the odds of using service for those having internet access less than that the odds of using service for those not having access to internet by $39 \%$. Also, the odds of using service for those having a smartphone that can use to access the internet is 7 times the odds of using service for those not having a smartphone that can use to access the internet. The same for having computers or tablets, the odds of using service for those having a computer or tablet at home that can use to access the internet is $\mathbf{5}$ times the odds of using service for those don't have a computer or tablet at home that can use to access the internet. Similarly, for having debit or credit card, the odd ratio is 9.780, the odds of using service for those having any debit or credit cards is 10 time the odds of using service for those don't have any debit or credit cards. The same ratio is 5.502 for using online payment before, reflecting the positive effect on demand as the odds of using service for those who bought or paid online before is 5 time the odds of using service for those who did not buy or pay online before. In respect to using online banking services, in spite of the fact that $80 \%$ of respondents do not have experience with online banking, the odd ratio is 7.742, then the odds of using service for those having any online banking service before is 8 time the odds of using service for those don't have any online banking service before. 
Citizen-centric Approach to e-government Ola AlSayed - Shadwa Esmat Accepted date 25/4/2021

Table (5): Distribution of answers to positive answers (Yes) and negative answers (No) according to Internet accessibility and usage and their correlation with accepting to use the service if applying for an electricity meter became available online

\begin{tabular}{|c|c|c|c|c|}
\hline \multicolumn{5}{|c|}{$\begin{array}{l}\text { The question that respondents had been asked to elicit their demand for the online service: } \\
\text { If applying for an electricity meter became available online, would you like to use this service? }\end{array}$} \\
\hline $\begin{array}{l}\text { Internet accessibility } \\
\text { and usage }\end{array}$ & Classifications of respondents & Yes & No & $\begin{array}{l}\text { Correlation } \\
\text { Coefficients }\end{array}$ \\
\hline \multirow[t]{2}{*}{ Internet Access } & $\begin{array}{l}20 \% \text { of respondents have access to } \\
\text { internet }\end{array}$ & $12.3 \%$ & $87.7 \%$ & \multirow{2}{*}{$\begin{array}{l}\text { Confidence interval } \\
(0.569-0.897) \\
\text { Odds ratio }=0.608\end{array}$} \\
\hline & $\begin{array}{l}80 \% \text { of respondents have access to } \\
\text { internet }\end{array}$ & $53.4 \%$ & $44.6 \%$ & \\
\hline \multirow[t]{2}{*}{ Having smartphones } & $\begin{array}{l}76 \% \text { of respondents have } \\
\text { smartphones }\end{array}$ & $92.8 \%$ & $7.2 \%$ & \multirow{2}{*}{$\begin{array}{l}\text { Chi-square (3.668- } \\
12.297) \\
\text { Odds ratio }=6.714\end{array}$} \\
\hline & $\begin{array}{l}24 \% \text { of respondents do not have } \\
\text { smartphones }\end{array}$ & $65.6 \%$ & $34.4 \%$ & \\
\hline \multirow[t]{2}{*}{$\begin{array}{l}\text { Having computers or } \\
\text { tablets }\end{array}$} & $\begin{array}{l}44.5 \% \text { of respondents have } \\
\text { computers or tablets }\end{array}$ & $94.9 \%$ & $5.1 \%$ & \multirow{2}{*}{$\begin{array}{l}\text { Chi-square }(2.330- \\
10.337) \\
\text { Odds ratio }=4.908\end{array}$} \\
\hline & $\begin{array}{l}55.5 \% \text { of respondents do not have } \\
\text { computers or tablets }\end{array}$ & $79.3 \%$ & $20.7 \%$ & \\
\hline \multirow[t]{2}{*}{$\begin{array}{l}\text { Having debit or credit } \\
\text { cards }\end{array}$} & $\begin{array}{l}23.8 \% \text { of respondents have debit or } \\
\text { credit cards }\end{array}$ & $97.9 \%$ & $2.1 \%$ & \multirow{2}{*}{$\begin{array}{l}\text { Chi-square }(2.336- \\
40.936) \\
\text { Odds ratio }=9.780\end{array}$} \\
\hline & $\begin{array}{l}76.2 \% \text { of respondents do not have } \\
\text { debit or credit cards }\end{array}$ & $82.6 \%$ & $17.4 \%$ & \\
\hline \multirow[t]{2}{*}{$\begin{array}{l}\text { Using online } \\
\text { payments before }\end{array}$} & $\begin{array}{l}27 \% \text { of respondents have } \\
\text { experience with online payments }\end{array}$ & $96.3 \%$ & $3.7 \%$ & \multirow{2}{*}{$\begin{array}{l}\text { Chi-square }(1.938- \\
15.619) \\
\text { Odds ratio }=5.502\end{array}$} \\
\hline & $\begin{array}{l}73 \% \text { of respondents do not have } \\
\text { experience with online payments }\end{array}$ & $82.5 \%$ & $17.5 \%$ & \\
\hline \multirow[t]{2}{*}{$\begin{array}{l}\text { Using online banking } \\
\text { services before }\end{array}$} & $\begin{array}{l}20 \% \text { of respondents have } \\
\text { experience with online banking }\end{array}$ & $97.5 \%$ & $2.5 \%$ & \multirow{2}{*}{$\begin{array}{l}\text { Chi-square }(1.845- \\
32.485) \\
\text { Odds ratio }=7.742\end{array}$} \\
\hline & $\begin{array}{l}80 \% \text { of respondents do not have } \\
\text { experience with online banking }\end{array}$ & $83.4 \%$ & $16.6 \%$ & \\
\hline
\end{tabular}

Source: constructed by the researchers 


\section{5-4: Experience with government services either traditional or digital:}

The fourth factor is the respondents' experience with government services, that includes two sub-factors, their experience with traditional applying for electricity meter and their experience with other online government services that are used in sectors other than electricity sector. The hypothesis (H9) reflects this factor in two sub-hypotheses (H9-1) and (H9-2).

By asking respondents about obstacles, quality and cost of traditional application, researchers could construct the hypothesis (H9-1). It stated that more obstacles, less quality and high cost of the traditional application have positive effect on demand for online application for this service if available. It is assumed that users will prefer the alternative, which is online application to avoid those obstacles of high cost and look for a higher quality service that could be available online. Whereas, hypothesis (H92 ) is which is based on the experience of respondents with using the online government services -either in terms of usage or evaluation. It is hypothesized that this experience has positive effect on the demand for online application for electricity meter, if available. As it reflects more trust in government as services provider. Both hypotheses are based on the assumption of the "relative advantage" "of the online service in terms of saving time, money, effort, or any other associated expenses of the traditional service.

Regarding the past experience of respondents in applying for electricity meter using traditional channel, the results as shown in

\footnotetext{
4 "Relative advantage" reflects the belief that a new system/service has benefits above and beyond the current one (Carter and Weerakkody, 2008)
} 
table (6), indicated that $42 \%$ of respondents applied for electricity meter before.

Table (6) shows the outcomes regarding testing hypothesis (H9). Results demonstrated rejection of sub-hypothesis (H9-1) as applying for electricity meter using the traditional method has no effect on demand on the online service if available. Quality and cost as well, have no effect on demand, as the confidence interval contains 1 so there is no relationship between the both factors and demand.

Similarly, the findings proofed rejection of (H9-2), as respondents' experience with online government services has no effect on the demand, as in spite of, $66 \%$ of respondents have information about the availability of online government services. But only $8 \%$ actually used these services, and their evaluation has insignificant effect on demand, which reflects low demand on available digital government services.

Table (6): Distribution of answers to positive answers (Yes) and negative answers (No) according to Respondents' Experience with Government Services and their correlation with accepting to use the service if applying for an electricity meter became available online

The question that respondents had been asked to elicit their demand for the online service: If applying for an electricity meter became available online, would you like to use this service?

\begin{tabular}{|l|l|l|l|l|}
\hline $\begin{array}{l}\text { Respondents' } \\
\text { Experience with } \\
\text { Traditional } \\
\text { applying for } \\
\text { electricity meter }\end{array}$ & $\begin{array}{l}\text { Classifications of } \\
\text { respondents }\end{array}$ & Yes & No & $\begin{array}{l}\text { Correlation } \\
\text { Coefficients }\end{array}$ \\
\hline $\begin{array}{l}\text { Traditional applying } \\
\text { for electricity meter }\end{array}$ & $\begin{array}{l}\text { 42\% of respondents } \\
\text { applied for electricity } \\
\text { meter }\end{array}$ & $\begin{array}{l}81 \% \text { for } \\
\text { Application } \\
\text { made } \geq 5 \\
\text { years ago } \\
88 \% \text { for } \\
\text { Application }\end{array}$ & $12 \%$ & $\begin{array}{l}\text { Chi-square value }=4.07 \\
\text { Chi-square } \\
\text { Sig.=0.083<5\% }\end{array}$ \\
\hline
\end{tabular}




\begin{tabular}{|c|c|c|c|c|}
\hline & & $\begin{array}{l}\text { made } \leq 5 \\
\text { years ago }\end{array}$ & & \\
\hline & $\begin{array}{l}58 \% \text { of respondents did } \\
\text { not apply for electricity } \\
\text { meter }\end{array}$ & $89.2 \%$ & $10.8 \%$ & \\
\hline \multirow{2}{*}{$\begin{array}{l}\text { Facing obstacles in } \\
\text { traditional applying } \\
\text { for electricity meters } \\
\text { from Egyptian } \\
\text { Electricity Holding } \\
\text { Company }\end{array}$} & $\begin{array}{l}17 \% \text { only of respondents } \\
\text { faced obstacles in } \\
\text { applying electricity meter }\end{array}$ & $72.1 \%$ & $27.9 \%$ & \multirow[t]{2}{*}{$\begin{array}{l}\text { Chi-square }(0.167- \\
0.590) \\
\text { Odds ratio }=0.314\end{array}$} \\
\hline & $\begin{array}{l}83 \% \text { of respondents did } \\
\text { not face obstacles in } \\
\text { applying electricity meter }\end{array}$ & $89.2 \%$ & $10.8 \%$ & \\
\hline \multirow{2}{*}{$\begin{array}{l}\text { Quality of } \\
\text { traditional } \\
\text { application }\end{array}$} & $\begin{array}{l}53 \% \text { evaluate it as low } \\
\text { quality }\end{array}$ & $51 \%$ & $49 \%$ & \multirow{2}{*}{$\begin{array}{l}\text { Confidence interval } \\
(0.854,1.237) \\
\text { Odds ratio }=1.08\end{array}$} \\
\hline & $\begin{array}{l}47 \% \text { evaluate it as high } \\
\text { quality }\end{array}$ & $48 \%$ & $52 \%$ & \\
\hline \multirow[t]{2}{*}{$\begin{array}{l}\text { Cost of traditional } \\
\text { application }\end{array}$} & $\begin{array}{l}56.5 \text { evaluate the cost of } \\
\text { traditional service as low }\end{array}$ & $48.1 \%$ & $51.9 \%$ & \multirow{2}{*}{$\begin{array}{l}\text { Confidence interval } \\
(0.709,1.213) \\
\text { Odds ratio }=1.13\end{array}$} \\
\hline & $\begin{array}{l}43.5 \text { evaluate the cost of } \\
\text { traditional service as high }\end{array}$ & $47.9 \%$ & $52.1 \%$ & \\
\hline $\begin{array}{l}\text { Respondents' } \\
\text { Experience with } \\
\text { online Government } \\
\text { Services }\end{array}$ & $\begin{array}{l}\text { Classifications of } \\
\text { respondents }\end{array}$ & Yes & No & $\begin{array}{l}\text { Correlation } \\
\text { Coefficients }\end{array}$ \\
\hline \multirow[t]{2}{*}{$\begin{array}{l}\text { Using online } \\
\text { government services } \\
\text { before }\end{array}$} & $\begin{array}{l}7.8 \% \text { only of respondents } \\
\text { used available online } \\
\text { government services } \\
\text { before }\end{array}$ & $96.8 \%$ & $3.2 \%$ & \multirow[t]{2}{*}{$\begin{array}{l}\text { Chi-square }(0.687- \\
38.505) \\
\text { Odds ratio }=5.143\end{array}$} \\
\hline & $\begin{array}{l}92.2 \% \text { only of } \\
\text { respondents did not use } \\
\text { available online } \\
\text { government services } \\
\text { before }\end{array}$ & $85.4 \%$ & $14.6 \%$ & \\
\hline \multirow{3}{*}{$\begin{array}{l}\text { Evaluating online } \\
\text { government } \\
\text { services, the } \\
\text { respondents used } \\
\text { before }\end{array}$} & $27 \%$ evaluated it as bad & $100 \%$ & $0 \%$ & \multirow{3}{*}{$\begin{array}{l}\text { Chi-square value }= \\
1.805 \\
\text { Chi-square } \\
\text { Sig. }=0.406<5 \%\end{array}$} \\
\hline & $\begin{array}{l}36.5 \% \text { evaluated it as } \\
\text { medium }\end{array}$ & $100 \%$ & $0 \%$ & \\
\hline & $\begin{array}{l}36.5 \% \text { evaluated it as } \\
\text { excellent }\end{array}$ & $91.7 \%$ & $8.3 \%$ & \\
\hline
\end{tabular}

Source: constructed by the researchers 


\section{5-5: Accepting to pay extra fees (user charges) to get online} service and WTP maximum amount:

A question about accepting to pay the extra fees to get the online service, if available was asked to the sample. The results showed that $45 \% \%$ of respondents accept paying extra fees to get the online services, while $55 \%$ refused.

The results of the question that were asked to elicit the respondents' maximum WTP as user charges to use the online service of installing the electricity meter if available, appear in table (7). The Maximum amount of money to be paid as extra fees recorded for a respondent is $300 \mathrm{LE}$. While the Minimum amount of money to be paid as extra fees recorded for a respondent is 1LE. And the Average amount of money that people accept to pay for as extra fees is approximately $50 \mathrm{LE}$.

Table (7): Average willingness to pay as extra fees to get the specified online service:

\begin{tabular}{|c|c|c|c|c|c|}
\hline \multicolumn{6}{|c|}{ Descriptive Statistics } \\
\hline & $\begin{array}{c}\text { Number } \\
\text { of } \\
\text { responden } \\
\text { ts } \\
\end{array}$ & $\begin{array}{c}\text { Minimum } \\
\text { WTP }\end{array}$ & $\begin{array}{c}\text { Maximum } \\
\text { WTP }\end{array}$ & Mean & Std. Deviation \\
\hline $\begin{array}{l}\text { What is the maximum } \\
\text { amount you accept to pay } \\
\text { as extra fees added to the } \\
\text { cost of getting the service } \\
\text { (installing the electricity } \\
\text { meter) in case of getting } \\
\text { the service online? }\end{array}$ & 156 & 1 & 300.0 & $\begin{array}{c}48.93 \\
7\end{array}$ & 74.6021 \\
\hline
\end{tabular}

Source: constructed by the researchers 


\section{6- Discussion:}

The digital transformation becomes imperative, and accordingly it is also essential to understand the factors that affect demand for the online service, not only theoretically, but also from a managerial and empirical perspective.

The results of the study confirm many of the research hypotheses as appears in Table (8).

Table (8): Hypotheses Testing:

\begin{tabular}{|l|l|l|}
\hline Variable & Hypothesis & Support \\
\hline Residence & H1 & Reject \\
\hline Gender & H2 & Accept \\
\hline Age & H3 & Accept \\
\hline Social status & H4 & Accept \\
\hline Average monthly salary & H5 & Accept \\
\hline Educational level & H6 & Accept \\
\hline $\begin{array}{l}\text { Knowledge about existing } \\
\text { online government services }\end{array}$ & H7 & Accept \\
\hline Internet accessibility and usage & H8 & Accept \\
\hline $\begin{array}{l}\text { respondents' experience with } \\
\text { government services }\end{array}$ & H9 & $\begin{array}{l}\text { Reject H9-1 } \\
\text { Reject H9-2 }\end{array}$ \\
\hline
\end{tabular}

\section{Source: constructed by the researchers}

The hypotheses related to the demographic variables, age (H3), average monthly salary/income (H5) and level of education (H6) were accepted. The results showed that they have an effect on demand for the application for electricity meter, if available online. This finding is consistent with previous research in this area (Colesca and Dobrica, 2008), which found that age and 
education have a significant impact on the demand for egovernment services.

The results also showed that Gender (H2) and Social Status (H4) have no effect on the demand for online application for electricity meter, if available. Though Colesca and Dobrica (2008) failed to link income and demand for the e-government service, on the opposite of this study, however they are also providing a consistent result with this study regarding gender.

The only rejected hypothesis of the demographic-related hypotheses is (H1) that stated the area of residence has no effect on demand for online application for electricity meter, if available. The study showed that there is a weak relationship between residence and using the online service, if available. Since the sample was collected from 3 governorates Cairo (the capital), Giza and Qalyobia, this result can be justified. The further citizens from the capital, the less urbanized and accordingly an expected lower demand for digital service.

Knowledge about existing online government services (H7) appears to have an effect on the demand for online application for electricity meter if available, which means accepting H7. This would mean that informing citizens about e-government services and their benefits is a vital factor in creating more demand for egovernment services (Carter and Weerakkody, 2008).

The study shows empirical evidence that supports (H8) that internet accessibility and usage have positive effect on demand for online application for electricity meter if available. Though this result contradicts with Carter and Weerakkody, (2008) who concluded that internet accessibility and skill were not significant determinants of e-government adoption in U.K. However, they 
also justified this by cultural differences, where digital divide ${ }^{5}$ can be a determinant of demand for e-government services. Their justification was later supported by the results of (Alomari, Sandhu and Woods, 2013) study in Jordan. According to the later study, digital divide (represented in different ways like internet accessibility divide, region and technology infrastructure divide, income divide) is one of the reasons why Jordanians do not use egovernment services. Their result is consistent with this study. It has the implication that digital divide has an effect on demand for e-government service, but it differs according to cultures and the digital divide is present in developing countries and the Arab world.

This finding is also supported by (Carter and Belanger, 2005). Though they used a different concept which is "compatibility", but it reflects the same idea. Compatibility is about the regular use of citizens to the internet, as part of their lifestyle. They found that compatibility has a significant impact on demand for egovernment services. This supports our finding of the positive effect of using online payment or online banking services (subfactors of H8) on demand for online application for electricity meter if available.

Unexpected results worth evaluating too. Hypothesis (H9) with its two sub-hypotheses were rejected. (H9-2) was rejected suggesting that prior experience of respondents with online government services either expressed by their usage or by evaluation have no effect on demand for online application for electricity meter if available. This contradicts with (Colesca and Dobrica, 2008) findings that users with prior internet experience,

${ }^{5}$ Digital divide refers to the gap between the people who do and do not have access to the internet and computers (Alomari, Sandhu and Woods, 2013). 
especially if satisfied, would be more likely to use e-government services. Also, our study contradicts with their result that quality of online service enhances citizens satisfaction and implicitly the level of adoption of e-government.

These findings can be justified by looking deeper into the results of the survey. Only $8 \%$ of the sample have prior experience with the online government services, while $92 \%$ of the sample have never used any of the online government service. So, there is not much prior experience with the e-government service found in the sample.

And of the small group who had such experience, when respondents were asked about the problems they faced, $45 \%$ stated that the main problem they faced in their use of egovernment service was "internet connections". This result reflects the impact of the digital divide, which again supports $\mathrm{H} 8$. It implies that governments should work harder to overcome the impacts of the digital divide if it wants more citizens to use eservices. On the other hand, $21.2 \%$ of the sample who had prior experience with online government services said they faced difficulty in registering data and problems on the website itself. This can be related to the concept of "ease of use" that was considered as a significant determinant of demand for egovernment services by (Carter and Belanger, 2005, Colesca and Dobrica, 2008, Al-Hurjan et al.,2015) or as referred to by (Ahmed, Markkula and Oivo, 2013) as "effort expectancy". This also implies that governments should make e-government services easier and more usable to citizens.

Interestingly as well, (H9-1) was rejected suggesting that applying for electricity meter using the traditional method has no effect on demand for online service, and neither the quality nor the cost of the traditional service. This result is surprising even 
more by revising the respondents' answers to the question about the obstacles they faced with the traditional application for the electricity meter, where they could have chosen more than one reason. That question was answered by the whole sample, whether users or non-users of the service. Thus, it also reflects the perceived obstacles by non-users. $75 \%$ of the respondents chose the obstacle that traditional procedures take time (routine), $65.5 \%$ chose crowdedness, $52 \%$ paperwork needed (time and cost of photocopying), $46 \%$ paying tips, $15.5 \%$ distance, and $15.5 \%$ transportation cost.

Despite the above obstacles of the traditional service mentioned by the respondents, the correlation analysis unexpectedly showed that they have no effect on demand for e-government service. This might reflect the absence of or weak awareness among the sample about the "relative advantage" or "perceived usefulness" of the e-government services that could help them overcome the obstacles of the traditional method. Some researchers consider the two concepts of relative advantage and perceived usefulness to be the same, while others do not (Carter and Belanger, 2005). These two important concepts are considered among the significant factors affecting demand for e-government services by (Colesca and Dobrica, 2008, Carter and Weerakkody, 2008, Alomari, Sandhu, and Woods, 2013) and was referred to as "performance expectancy" by (Ahmad, Markkula and Oivo, 2013), and as "perceived public value" by (Al-Hurjan et al., 2015).

This surprising result can also be associated with level of knowledge about existing online government services (H7). As suggested by the accepted hypothesis; increasing citizens' level of knowledge might affect the demand for the e-government services. So, this implies that the government may make trainings or awareness programs that explain the relative advantage of the 

of the obstacles of the traditional method.

That conclusion is further supported by the response of the group who refused to get the online service, if available (almost $14 \%$ of the sample) when they were asked in the survey about the reasons behind refusal. They could choose more than one reason. $63 \%$ of this group chose the reason that they do not think the government can provide the e-service efficiently. That can be linked to the factor of "trust in government" where there appears to be a lack of trust in the government as one of important reasons why $14 \%$ of the sample refuse the online service. Using factor analysis, the study results showed that $90.5 \%$ of respondents expressed low trust in government services, while $9.5 \%$ expressed high trust. This is consistent with the conclusions of (Carter and Belanger, 2005, Colesca and Dobrica, 2008, Al-Hurjan et al., 2015,) that trust in government as a provider of e-service is a significant factor affecting citizens demand for such services.

All the other reasons specified by the sample are also supported by the literature. $45 \%$ said that they prefer the traditional method. This can be explained by the lack of awareness about relative advantage of e-government services or the digital divide explained above. $25 \%$ said they fear of sharing information online. This can be related to the concept of "trust in the internet" referred to by (Carter and Weerakkody, 2008, Alomari, Sandhu and Woods, 2013, Carter and Belanger, 2005). 20\% do not know how to use the internet. This supports the concept of "internet skills" as a factor affecting demand for e-government (Carter and Weerkkody, 2008, Alomari, Sandhu and Woods, 2013) While $12.7 \%$ had prior bad experience with the online, which is a reinforced factor by (Colesca and Dobrica, 2008) Thus, all of those results are consistent with the literature and the factors that affect demand for e-government services. 
If we look deeper at the $86 \%$ of the sample who agreed to apply for electricity meter online, if available, they were asked about the advantages they see in the online government service. Most of the sample thought that advantage is revolving around saving effort (62\%), saving time (58\%), saving cost (29.5\%), avoid crowdedness $(58.75 \%$ ), while $20 \%$ said it helps avoiding the spread of coronavirus. All the factors mentioned here again supports the importance of relative advantage or perceived usefulness of e-government service as factors affecting demand. Another striking result was the percentage of the sample who has a WTP for the e-government service, if available. Though $86 \%$ of respondents have demand for the specified e-government service, given the perceived usefulness explained above, only $45 \%$ showed their willingness to pay extra fees to get that egovernment service if available. And the average amount they are willing to pay is $50 \mathrm{~L}$.E. This result reflects that respondents have a demand but not an effective demand, for the specified egovernment service, if available, since more than half of the sample are not willing to pay extra fees to get that service. Such interesting results inspires the researchers to try to explore and investigate more -in a new paper- the factors that affects the respondents' willingness to pay to get the specified e-government service if available.

\section{7- Conclusion}

The study tested nine hypotheses via survey method and correlation measures to detect the factors affecting demand for online applying for electricity meter in a sample of 400 respondents in Greater Cairo during July-August 2020. Seven of hypotheses were accepted, while only two were rejected. The survey showed that the demand for e-government service is 
affected by some demographic characteristics (area of residence, age, income, and education), level of knowledge about available online government services, internet use and accessibility or digital divide. In addition, relative advantage or perceived usefulness, ease of use and lack of trust showed indirect or implicit effect on the demand for e-government services that was revealed from citizens' answers to the survey. Such conclusions give some insights for policymakers and practitioners who are responsible for developing and running e-government services. These findings can suggest the following implications:

Implications regarding the design and implementation of $e$ government services:

When designing e-government services, the government may start with e-services that target younger generation, highly educated and middle-income citizens. Since the three demographic variables showed an effect on the demand for eservices, so the government may choose to direct or start with the e-services that is needed most by these categories. Thus, determining the target groups of the e-government service in advance, can facilitate the transformation from traditional to digital service. This in fact requires further research to investigate even more on the sectors where citizens may prefer e-service.

It is also imperative for the government before putting more investment in e-services, to work on reducing the digital divide and ensure the availability of internet access on a wider scale, especially in rural areas. This can help create more demand for the e-government service that justify the investment.

Since the study demonstrated that knowledge about available online government services can affect demand, so, the government should consider raising awareness about the 
available e-government services through different media channels.

To ensure ease of use, the government should design websites and application forms that can be easily used and understood by citizens. It might also provide tutorials on the websites that explain all the steps needed to get the online service. It might also provide training if needed that can also help in raising more awareness about the e-government services.

On the other hand, the government must highlight the relative advantage or perceived usefulness of e-government services to citizens. It should also emphasize the way e-government service can help citizens overcome the obstacles of the traditional method. This can be done by increasing citizens' awareness about the value of using e-government services, providing them with training workshops and awareness programs to explain the relative advantages of e-government services.

To overcome the lack of trust, government should try to make strategies to build trust with citizens. It should open more channels of communication with citizens, take advantage of egovernment services to promote the public values of trust, time and money value, respect, participatory relationship between citizens and government.

The success of e-government services depends largely on how well it creates public value for citizens. This is supposed to be achieved through providing citizens with easier channels to access public service, saving time and money (economic value and time value), and promoting more government-citizen interactions (Al-Hurjan et al., 2015) Government should try to make e-government services more valuable to citizens.

Implications regarding the financing of e-government services: 
One of the main aims of this research was to determine the most appropriate financing source for the e-government services (government budget, partnership with the private sector, or private sector alone). The study results showed that only less than half of the sample ( $45 \%$ of sample) were ready to pay extra fees to get the e-government service. This indicates a low level of willingness to pay for extra fees among the sample. Accordingly, the study recommends that the government should currently avoid thinking of the private sector as a sole source of fund for egovernment service. But it should either depend completely on the state budget or a partnership with private sector. Choosing between the two methods shall depend upon surveys aiming at revealing citizens' willingness to pay for extra fees to get the eservice. If the results showed low WTP, then the state should be responsible for the finance. But, if it showed high WTP, this could encourage the government to go for a partnership with the private sector, since there will be revenues and profits for the private sector.

Consequently, all the mentioned implications and recommendations shall ensure the optimum use of resources by the government. This is because it should lead to avoid providing digital services -with all the associated financial burden- that citizens may have low demand for or refrain from using and continuing to use the traditional method. That will represent a great loss for the limited resources. On the other hand, full finance through the state budget supported by existing demand and WTP will generate positive externalities for the whole society. And lastly, the partnership with the private sector is expected to succeed when there is high WTP, and thus reduce the burden on the state budget and help in having better use of the state resources. 
Since this study is applied on one service and one sector electricity sector- and on Greater Cairo, thus, further studies are needed to investigate citizens' demand and WTP in other sectors. Also, more studies on other governorates are recommended, especially remote and border governorates where there are differences in demographics, income, and education level. On the other hand, given that the research's focus was on the demand of households, therefore, additional studies can focus on the business sector to explore their demand and WTP for digital government services.

\section{References}

Ahmed, M.O., J. Markkula and M. Oivo (2013), "Factors affecting e-government adoption in Pakistan: a citizen's perspective", Transforming Government: People, Process and Policy, Vol. 7 (2), pp. 225-239.

Agresti, A., (2007), "An Introduction to Categorical Data Analysis", Hoboken, NJ: Wiley-Interscience.

Al-Hujran, O., M.M. Al-Debei, A. Chatfield, and M. Migdadi (2015), "The Imperative of Influencing citizen attitude toward egovernment adoption and use", Computers in Human Behavior, Vol.53, pp.189-203.

Alomari, M.K., K. Sandhu and P. Woods, (2014), "Exploring citizen perceptions of barriers to e-government adoption in a developing country", Transforming Government: People, Process and Policy, Vol. 8 (1), pp. 131-150.

AlShehri, Mohammed and Steve Drew (2010), E-government Fundamentals, Proceedings of IADIS International Conference ICT: Society and Human Beings 2010, Australia.

AlShehri, Mohammed and Steve Drew (2010), “Challenges of EGovernment Services Adoption in Saudi Arabia from an E-Ready 
Citizen Perspective", "World Academy of Science, Engineering and Technology”, Vol (42), pp.1039-1045.

AlShehri, Mohammed, and Steve Drew (2011), "E-government principles: implementation, advantages and Challenges", International Journal of Electronic Business, Vol. 9 (3).

AlShehri, Mohammed, Steve Drew and Osama AlFarrag (2012), “A Comprehensive Analysis of E-Government Services Adoption in Saudi Arabia: Obstacles and Challenges", International Journal of Advanced Computer Science and Application, Vol. 3 (2).

Al-Shboul, Muhannad, Osama Rababah, Moh'd Al-Shboul, Rawan Ghnemat and Samar Al-Saqqa (2014), "Challenges and Factors Affecting the Implementation of E-Government in Jordan", Journal of Software Engineering and Applications, Vol. 7, p.p. 1111-1127.

Basamh, Salem, Hani A.Qudaih and Mohd Suhaimi (2014), "EGovernment Implementation in the Kingdom of Saudi Arabia: An Exploratory Study on Current Practices, Obstacles and Challenges", Journal of Humanities and Social Science, Vol.4 (2).

Black, K., (1994), "Business Statistics: Contemporary Decision Making", Minneapolis: West Pub.

Bryson, John M., Barbara C. Crosby and Laura Bloomberg (2014), "Public Value Governance: Moving Beyond Traditional Public Administration and the New Public Management", Public Administration Review, Vol. 74 (4), pp. 445-456.

Buchanan, James M. (1965), "An Economic Theory of Clubs", Economica, Vol.32 (125), pp.1-14

Bychkova ,Olga (2011), "Categories of goods in economics and public choice literature as applied to heat and water utilities", In: Kharkhordin, Oleg and Risto Alapuro (eds.), "Political Theory and Community Building in Post-Soviet Russia Routledge".

Carter, L., and F. Belanger (2005), "The utilization of e-government services: citizen trust, innovation and acceptance factors", Information Systems Journal, Vol. 15 (1), pp.5-25.

Carter, L., and V. Weerakkody (2008), "E-government adoption: A cultural comparison, Information Systems Frontier, Vol. 10 (4), pp. 473-482. 
Chen, Yu-Che and Kurt Thurmaier (2008), "advancing EGovernment: Financing Challenges and Opportunities", Public Administration Review, Vol. 68 (3), pp. 537-548.

Colesca, S. E., and L. Dobrica (2008), "Adoption and use of egovernment services: the case of Romania", Journal of Applied Research and Technology, Vol. 6 (3), pp. 204-217.

Cordella, Antonio, and Carla M. Bonina (2012), "A Public Value perspective for ICT enabled public sector reforms: A theoretical reflection", Government Information Quarterly, Vol. 29. pp. 512520.

Edmiston, Kelly D. (2003), "State and Local E-Government Prospects and Challenges", The American Review of Public administration, Vol. 33(1), pp. 20-45.

FAO (2000), "Applications of the contingent valuation method in developing countries: A survey", FAO Economic and Social Development

146.http://www.fao.org/3/X8955E/x8955e00.htm

Hayman, David N. (2010), "Public Finance: A Contemporary Application of Theory to Policy", $10^{\text {th }}$ Edition, South-Western Cengage Learning.

Holden, Stephen H., Donald Norris and Patricia D. Fletcher (2003), "Electronic Government at the Grass Roots: Contemporary Evidence and Future Trends", Public Performance and Management Review, Vol. 5, pp. 1-8.

Hwang, Min-Shiang, Chun-Ta Li, Jau-Ji Shen and Yen-Ping Chu (2004), "Challenges in E-Government and Security of Information, Information and Security (I\&S)", An International Journal, Vol. 15(1), pp. 9-20.

Johnson, Craig, Diana Gant and Jon Gant (2002), "State Web Portals: Delivering and Financing E-Service, E-Government Series", PricewaterhouseCoopers Endowment for the Business of Government.

Keller.G, Warrack.B, (1999). "Statistics for Management and Economics", United states of America: Duxbury press.

Layne, Karen and Jungwoo Lee (2001), "Developing Fully Functional E-Government: A Four Stage Model", Government Information Quarterly, Vol. 18, pp. 122-136. 
Nath, Anupam K. and Debjani Kanjilal (2014), "Challenges and Obstacles of E-Government Streamlining: A Case Study", International Journal of Business and Social Research, Vol. 4(5).

Noris, Donald F. and M. Jae Moon (2005), "Advancing EGovernment at the Grassroots: Tortoise or Hare?", Public Administration Review, Vol. 65(1).

Ojha, Shashank and I.M. Pandey (2017), "Management and Financing of E-Government Projects in India: Does Financing Strategy Add Value?", IIMB Management Review, Vol. 29, pp. 90108.

Rabaa, Ahmed (2015), "An Empirical Investigation on the Adoption of e-government in Developing Countries: The Case of Jordan", Computer and Information Science, Vol. 8 (3), pp. 83-102.

Rogers, Colin (2010), "The Principle of Effective Demand: The Key to Understanding The General Theory", In: Robert W. Diamond, Robert A Mundlell and Alssandro Vercelli (eds.), Keynes's General Theory after Seventy Years, International Economic Association Series.

Siddiqi, Jawad I.A., Mohamed Btoush and Raid Al-Adaileh (2009), "Barriers and Challenges in E-Government Services: an Empirical Study in Jordan", Conference Paper, International Conference on Technology, Innovation and Industrial Management, June $18^{\text {th }}-19^{\text {th }}$, Bangkok, Thailand.

Signore, Oreste, Franco Chesi and Maurizio Pallotti (2005), "EGovernment: Challenges and Opportunities", GMC Italy - XIX Annual Conference, (7-9) June, Florence, Italy.

Tassabehji, Rana, Ray Hackney and Takao Maruyama (2019), "Evaluating digital public services: A contingency value approach within three exemplar developing countries" Information Technology and People, Vol. 32 (4), pp. 1021-1043.

United Nation (2020),UN E-Government Knowledgebase, EGovernment Development Index (EGDI). https://publicadministration.un.org/egovkb/en-us/Data/Region-

Information 